Australian Journal of

Crop Science

AJCS

AJCS 13(11):1901-1907 (2019)

ISSN:1835-2707

doi: 10.21475/ajcs.19.13.11.p1480

\title{
Growth and production of soybean in response to spatial arrangement in savannah climate
}

\author{
Artur Sousa Silva*1, Amanda Soares Santos', Assussena Carvalho Miranda', Odália Carolinne Mota de Sousa', \\ Cibele Divino Aguiar', Jeissica Taline Prochnow' ${ }^{1}$, Fabio Mielezrski²
}

'University Federal of Piauí, Campus Profa Cinobelina Elvas, Bom Jesus, PI, Brazil

${ }^{2}$ University Federal of Paraíba, Areia, PB, Brazil

*Corresponding authors: Artur12_2010@hotmail.com

\begin{abstract}
The management of spatial arrangement in soybean culture (Glycine max L., Merrill) from seeding density and row spacing is an important tool that contributes to yield growth. The objective of this study was to evaluate the influence of spatial arrangement in the development and the production components of soybean in the Piauí Cerrado savanna. The experimental design was completely randomized, with subdivided plots and four replicates. The main plots consisted of different row spacing $(17.5 \mathrm{~cm}, 25 \mathrm{~cm}, 50 \mathrm{~cm}$ and 76 $\mathrm{cm})$ and subplots consisted of plant populations as follows: recommended (280,000 plant/ha); $50 \%$ below recommended; $50 \%$ and $100 \%$ higher than recommended. The subdivided plots had six lines of five metres in length. The highest growth component values (plant height, stem diameter and number of nodes) were observed in the larger spacing $(50 \mathrm{~cm}$ and $76 \mathrm{~cm})$ and lower populations (recommended and $50 \%$ below recommended). The highest component yield values (number of grains per pod, number of grains per plant, number of pods per plant, weight of one thousand seeds and productivity) were observed in the larger spacing (50 cm and $76 \mathrm{~cm}$ ) and in the recommended population for the cultivar.
\end{abstract}

Keywords: seeding density; row spacing; increment yield; Glycine max L.

Abbreviations: Prod_Productivity, PRODt_transformed productivity, RS_row spacing,PP_plant population, PH_plant height,NP_number of pods per plant, GP_number of grains per pod, GPL_number of grains per plant,WTS_weight of one thousand seeds.

\section{Introduction}

Several factors related to environment and management practices and plants are associated with low productivity in cropping. Among management practices, plant arrangement, whether by plant population variation or line spacing, should be emphasized, since it determines the expression of yield components and grain productivity by influencing the degree of intraspecific competition (Rahman and Hossain, 2011).

Soybean (Glycinemax L. Merrill) presents great plasticity in response to plant spatial arrangement, affecting the number of branches, pods, grains per plant and stem diameter, all of which are inversely proportional to the population (Silva et al., 2010). Cox and Cherney (2011) stated that there is a greater response from soybean in row spacing, with a tendency for higher yields in reduced spacing. In contrast, such spacing can provide a microclimate favourable for pathogens to attack, as observed by Lima et al. (2012), where Asian soybean rust had a severe effect on soybeans due to reduced spacing between lines and shading.

Several authors, using different plant densities and cultivars, have observed characteristics of soybean plasticity in the morphological expression of some vegetative components such as plant height, first pod insertion, branching and number of pods (Marchiori et al., 1999; Paiva et al., 1992; Tourino et al., 2002; Mauad et al., 2010; Ludwig et al., 2010 and Ludwig et al., 2011).

Basol et al. (2013) state that the population performs best with 450,000 to 600,000 seeds per hectare ( 20 to 27 seeds per metre, calculated with $0.45 \mathrm{~m}$ spacing). Petter et al. (2016) using soybean populations of $8,12,16,20$ and 24 seeds per metre (calculated with $0.40 \mathrm{~m}$ line spacing) and evaluating the dynamics of photosynthetically active radiation in the Piaui Cerrado savanna, found better results for the solar used in populations of 8 and 12 seeds per metre. According to Cruz et al. (2015), spatial arrangement changes the architecture of the soybean plants, and the increase in sowing density increases the grain yield of the soybean.

Plant height, bedding plant, and closed spacing between the lines are influenced by growth conditioning factors, such as climate, sowing period, soil fertility and cultivar (Silva et al., 2010). To avoid losses in productivity and production studies are needed that evaluate the influence of spatial arrangement on the agronomic characteristics of the plant and to determine the most suitable for each region, taking into account environmental conditions of the plant. 
Therefore, due to the lack of studies related to the spatial arrangements of soybean cultivation in MATOPIBA, which is very promising for agriculture, in addition to technological advances in production with development of new plant materials for this region, the objective of this study was to evaluate the influence of spatial arrangement on the development and production components of soybean plants in the Piauí cerrado savanna.

\section{Results and discussion}

\section{Response surface test}

Plant height (Table 2) and productivity (Table 3) were significantly influenced ( $p \leq 0.05$ ) by the spacing between the rows, by plant populations and by the interaction $\times$ population, and therefore, adjusted to the response surface methodology. For PRODt, the response surface methodology (Fig. 2) was adjusted with a coefficient of determination equal to $49.2 \%$ in relation to the variation of the values of the experimental units. This adjusted response surface has as a critical point a saddle point, (Prod $=1,991.9 \mathrm{~kg} \mathrm{ha}^{-1}$ ), considering the combination of $59.7 \mathrm{~cm}$ line spacing and a population of $299,453 \mathrm{ha}^{-1}$ plants. The occurrence of the saddle point means that the maximum or minimum productivity points cannot be obtained. However, in general, it seems that productivity decreases due to increasing spacing, as well as better results in the population of 280,000 plants ha $^{-1}$ (recommended). The relatively low value of the coefficient of determination of the model is due to the lack of consistency in the data of the climatic conditions of the experiment (Fig. 1), with a water deficit.

There is a better distribution of plants in the smaller spacing, thus improving the distribution of light in the lower layers of the canopy. Therefore, photosynthetic production is increased, resulting in an increase in grain yield. The results of this study agree with those of DeBruin and Pedersen (2008), Cox and Cherney (2011) and Singh (2011), which also showed higher yields of grains in the smaller row spacing.

The response surface methodology estimated for plant height (PH) has a coefficient of determination equal to $41.2 \%$ (Fig. 3). The critical point of this response surface results in a saddle point $(\mathrm{PH}=24.15 \mathrm{~cm})$ with the combination $\mathrm{RS}=54.4 \mathrm{~cm}$ and $\mathrm{PP}=489.526$ plants ha-1 and a range of height variation, within the limits studied, equal to $8.42 \mathrm{~cm}$. Regarding productivity, the determination coefficient for plant height was also low due to climatic conditions (Fig. 1). Plant height decreased due to the increase in population and spacing, contrary to the results observed in terms of productivity. This decrease may be due to the greater competition between plants since under extreme conditions, plants compete for the limited resources that are available, including light, therefore limiting their height development.

Mauad et al. (2010) state that in the greater spacing between plants, there is an increase in sowing density, so intraspecific competition by water, nutrients and mainly by light is increased, resulting in the weeding of the plants. Souza et al. (2016) found there was an increase in plant growth compared to the less dense ones when planting density is greater. The change in planting density changes the plant density in the line, thereby modifying plant height through population management (Mauad et al., 2010; Ludwig et al., 2010).

\section{Regression analysis}

The number of nodes showed no significant interaction and the simple effect was evaluated separately from each spacing and population (Table 3). For the number of nodes per plant, the linear model was the one that best fits the results obtained for spacing between plants (Fig. 4a). The number of nodes per plant increased due to the decrease in plant spacing. These results confirm that greater intraspecific competition generates greater growth and increases the number of branches per plant, and consequently the number of nodes, which was also observed by Mauad et al. (2010) and Lima et al. (2012).

There was a negative linear effect on the number of nodes per plant due to the increase in the population (Fig. 5a), which was also observed by Rambo et al. (2003). According to Cruz et al. (2016) and Souza et al. (2016), this is due to changes in the sowing density, which modify plant density in the line, in which population management modifies the plant architecture.

This behaviour is due to the competition between soybean plants caused by environmental growth factors, especially light. There is a lower availability of photosynthesis products for plant growth in a branch form and consequently in the nodes with higher plant density due to the increase in the number of plants per metre (Martins et al., 1999; Torres et al., 2015).

No significant effect was observed for the double interaction and spacing in the number of pods per plant, proving that the plant population interferes independently, since only this variable showed a statistically significant difference (Table 3).

The increase in the plant population caused a decrease in the number of pods (Fig. 5b), which may be due to the lower densities, less competition for light and greater availability of photoassimilates, making it easier for the plants to produce more pods. Tourino et al. (2002), Thomas and Costa (2010) and Cruz et al. (2016) also observed a decrease in the number of pods per plant as the plant population increased. Mauad et al. (2010) observed that the increase in sowing density linearly decreases the number of pods per plant.

The number of pods per plant is one of the plant production components that contribute to the greater tolerance in productivity to population change, varying inversely to the increase or decrease in the population (Peixoto et al., 2000).

The interaction between population and spacing did not show a significant difference for the variable number of grains per plant, whereas the simple effect was detected (Table 3). Fig. 4c shows that the increase in spacing provided a decrease in the number of grains per plant. According to Modolo et al. (2016) this result may be related to the better distribution of plants that occurs in the reduced spacing, thus improving the distribution of light in the lower layers of the canopy and, consequently, increasing photosynthetic production, contributing to the increase in grain yield. These results agree with studies by DeBruin and Pedersen (2008), Cox and Cherney (2011) and Singh (2011). 
Table 1.Chemical characterization of the soil in the 0 to $20 \mathrm{~cm}$ layer, sampled prior to the installation of the experiment

\begin{tabular}{|c|c|c|c|c|c|c|c|c|c|c|}
\hline $\mathrm{pH}$ & $\mathrm{P}$ & $\mathrm{S}$ & $\mathrm{K}$ & $\mathrm{Ca}$ & $\mathrm{Mg}$ & $\mathrm{Al}$ & $\mathrm{H}+\mathrm{Al}$ & CEC & V & OM \\
\hline$\left(\mathrm{CaCl}_{2}\right)$ & |-----ן & & & $\cdots$ & $\mathrm{dm}^{-3}$ & - & & & $\%$ & $\mathrm{~g} / \mathrm{dm}^{3}$ \\
\hline 4.2 & 13.3 & 4.7 & 0.6 & 11. & 2 & 2 & 22 & 36.6 & 39.4 & 10.7 \\
\hline
\end{tabular}

$\mathrm{pH}=$ Hydrogen potential, $\mathrm{P}=$ Phosphor, $\mathrm{S}=$ Sulfur, $\mathrm{K}=$ Potassium, $\mathrm{Ca}=$ Calcium, $\mathrm{Mg}=$ Magnesium, $\mathrm{Al}=$ Aluminum, $\mathrm{H}+\mathrm{Al}=$ Hydrogen + Aluminum, CEC = Cation exchange capacity, $\mathrm{V}=$ Base saturation, OM = Organic matter.

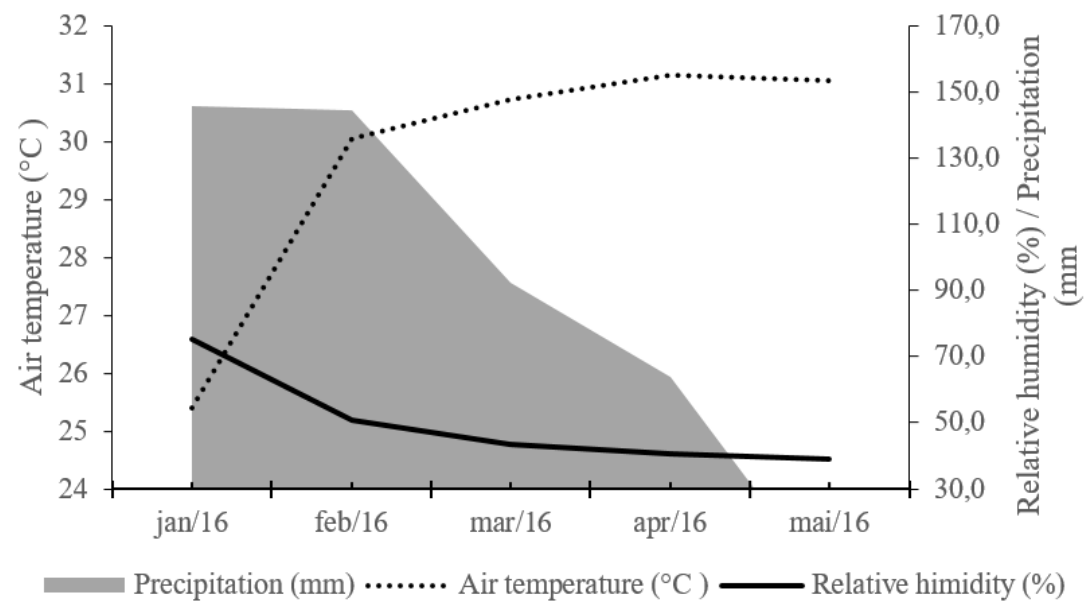

Fig 1. Mean monthly values of precipitation, air temperature and relative humidity during the months of conduction of the experiment.

Table 2. Analysis of variance of the growth components, Plant height and Number of nodes of soybean, as a function of row spacing (RS) and plant population (PP).

\begin{tabular}{lccc}
\hline \multirow{2}{*}{ SV } & \multicolumn{2}{c}{ Mean square } \\
\cline { 2 - 4 } & DF & Plant height & Number of nodes \\
\hline RS & 3 & $573.456^{* *}$ & $25.614^{* *}$ \\
PP & 3 & $7.905^{* *}$ & $2.732^{*}$ \\
RS X PP & 9 & $15.726^{* *}$ & $1.475^{\text {ns }}$ \\
Error & 30 & 4.161 & 0.983 \\
\hline CV\% & & 9.16 & 14,56 \\
\hline
\end{tabular}

${ }^{\text {ns }}$ Not significant; ${ }^{*}$ Significant (value $-p<0.05$ ) by the $F$ test; $S V=$ Source of variation = DF = Degrees of freedom; CV = Coefficient of variation.

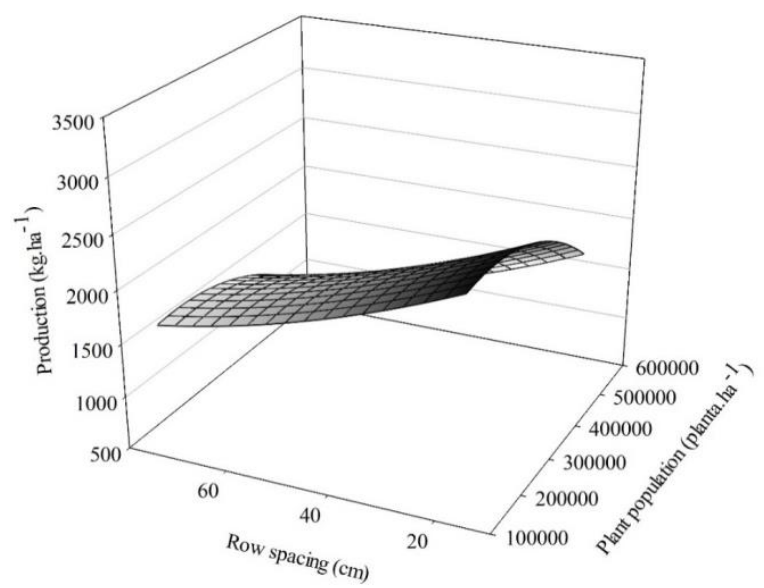

Fig 2. Production $\left(\mathrm{kg} \mathrm{ha}^{-1}\right)$ of soybean cultivated under different row spacing $(\mathrm{cm})$ and plant populations (plants ha-1) on the Savana Piauiense. 


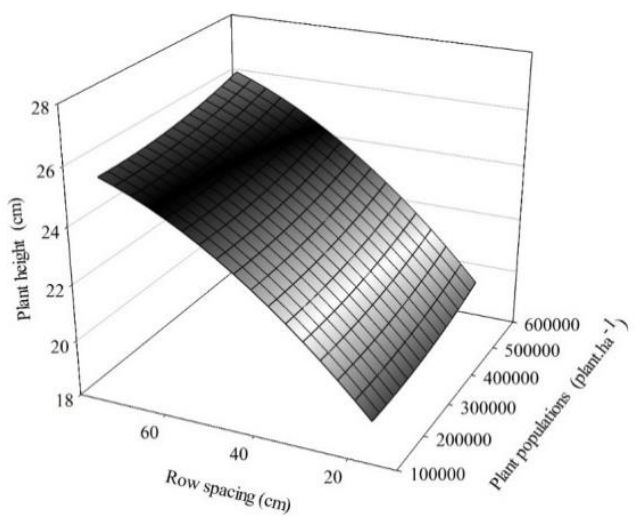

Fig 3. Effect of row spacing (LS) and plant populations (PP) on plant height (HEIG) of soybean.

Table 3. Variance analysis of yield components, productivity (PRODt), number of pods per plant (NP), number of grains per pod (GP), number of grains per plant (GPL) and Weight of one thousand seeds (WTS) of soybean, depending on row spacing (RS) and plant population (PP).

\begin{tabular}{lllllll}
\hline \multirow{2}{*}{ VF } & \multicolumn{7}{c}{ Mean square } \\
\cline { 2 - 7 } & DF & PRODt & NP & GP & GPL & WTS \\
\hline RS & 3 & $1.922 \mathrm{E}-7^{* *}$ & $61.890^{\text {ns }}$ & $1.081^{*}$ & $337.101^{* *}$ & $1346.079^{* *}$ \\
PP & 3 & $3.368 \mathrm{E}-7^{* *}$ & $315.190^{* *}$ & $0.186^{\text {ns }}$ & $902.811^{* *}$ & $863.882^{* *}$ \\
RS X PP & 9 & $5.547 \mathrm{E}-8^{* *}$ & $51.580^{\text {ns }}$ & $0.090^{\text {ns }}$ & $59.030^{\text {ns }}$ & $290.745^{\text {ns }}$ \\
Error & 30 & $2.160 \mathrm{E}-8$ & 37.341 & 0.104 & 54.827 & 173.032 \\
\hline CV $(\%)$ & & 18.04 & 18.79 & 20.07 & 18.92 & 10.11 \\
\hline
\end{tabular}

${ }^{\text {ns }}$ Not significant; ${ }^{*}$ Significant (value - $p<0.05$ ) by the $\mathrm{F}$ test; DF: Degrees of freedom; CV: Coefficient of variation.
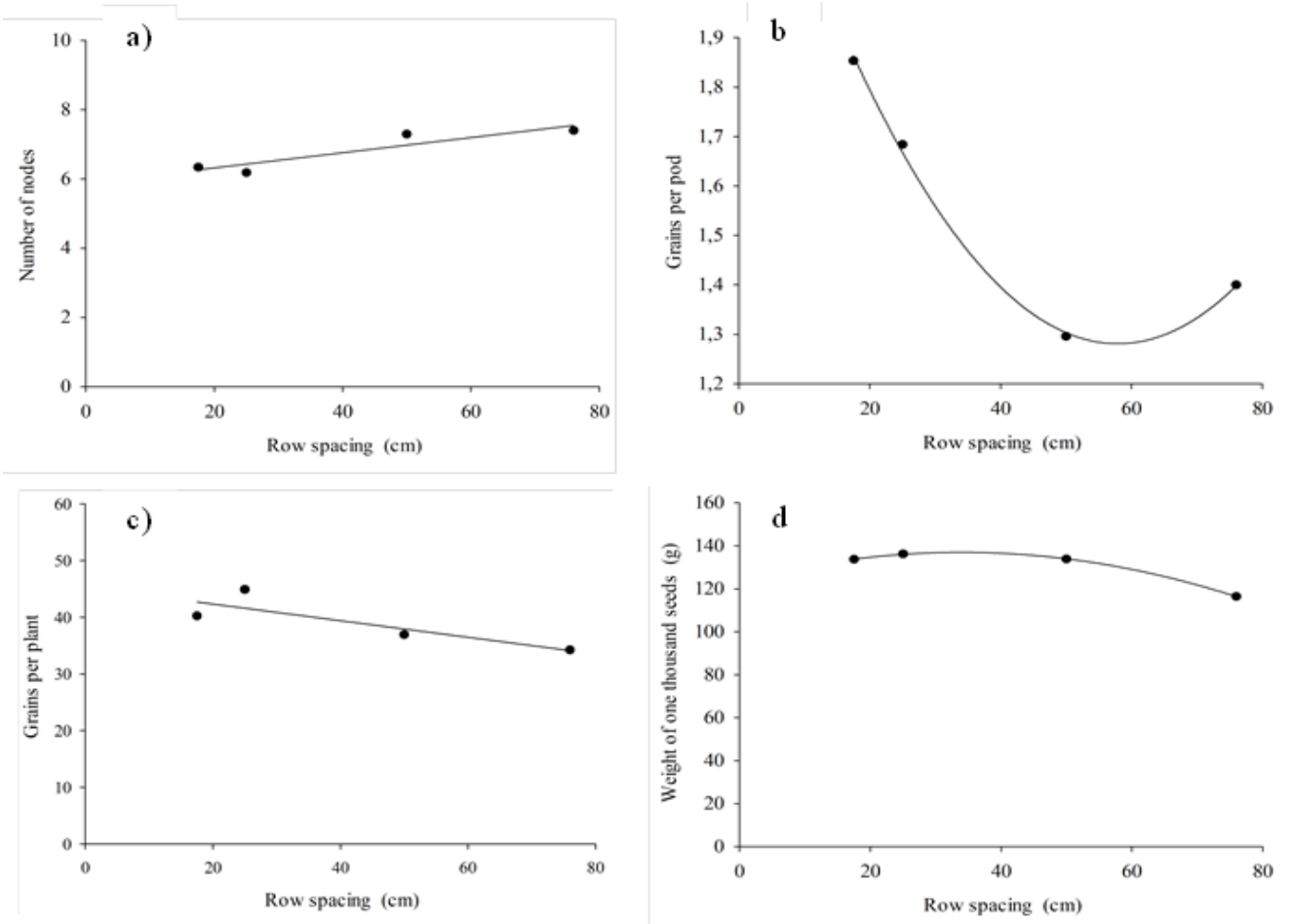

Fig 4. Number of nodes (a), Number of grains per pod (b), Number of grains per plant (c) and Weight of one thousand seeds (d) of soybean, as a function of row spacing. 

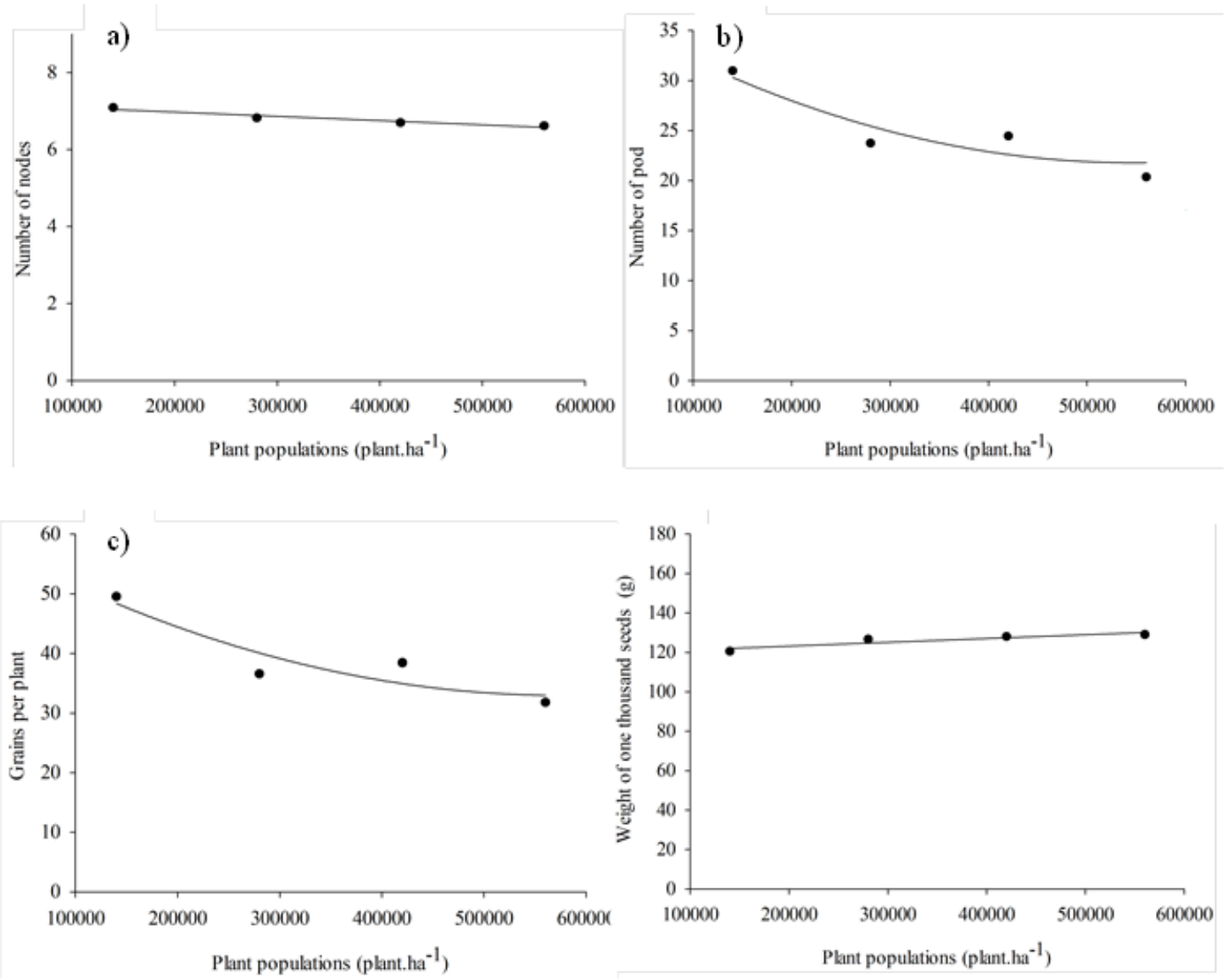

Fig 5. Number of nodes (a), Number of pod per plant (b), Number of grains per plant (c) and Weight of one thousand seeds (d) of soybean, as a function of plant populations.

There was a negative effect in the number of grains per plant as the population increased (Fig. 5c). Mauad et al. (2010) observed a decrease in the number of pods per plant and grains per pods with increasing densities, as a result of the present study. The same was also described by Tourino et al. (2002) and Cruz et al. (2016), associating these variables with the space compensation potential of the soybean plant.

Regarding the weight of a thousand seeds, a significance was observed only for the simple population effect and spacing (Table 3). The smaller spacing provided the highest weight values of one thousand seeds (Fig. $4 \mathrm{~d}$ ), a result also verified by Rambo et al. (2003). Pireset et al. (1998) observed a $25 \%$ higher average grain filling rate in reduced line spacing.

There was a linear increase in the weight of one thousand seeds following the increase in population (Fig. 5d). This may be due to the fact that in lower densities the plant was able to supply a greater amount of light, which is a crucial factor for maximizing productivity (Heiffig et al., 2006). Mauad et al. (2010) state that this is possibly due to the optimization of the spatial distribution of the plants, which contributes to the survival and greater capacity of the soybean in adjusting the yield components. Tourino et al. (2002) and Cruz et al. (2016) report that the mass of one thousand grains increases with the increase of plant density due to the decrease in the number of pods per plant (physiological drains), thus, there is less competition for photoassimilates that are concentrated in a smaller number of grains. The number of grains per plant was only significantly affected by spacing (Table 4). Mauad et al. (2010) reported that there is a decrease in the number of grains per pods with increased spacing and consequently density (Fig. 8). The same was also observed by Tourino et al. (2002) and Cruz et al. (2016).

Each cultivar has its own spacing requirements necessary for full development and, consequently, it can show its productive potential within the edaphoclimatic and handling conditions to which it was submitted. Thus, the results from the study represent characteristics of the cultivar used, while other cultivars may have different needs.

\section{Materials and methods}

\section{Characterization of the area}

The experiment was conducted in a field in the municipality of Currais located in the state of Piauí, Brazil, coordinates $9^{\circ}$ 3 '25.69" south latitude and $44^{\circ} 33^{\prime} 12.89^{\prime \prime}$ west longitude, altitude of 570 metres, in the agricultural year of 2016.According to Köppen climate classification, the climate of the region is Aw, tropical climate with dry season and with an average annual temperature of $26.4^{\circ} \mathrm{C}$. This region has an average annual rainfall of $986 \mathrm{~mm}$ with concentrated rainfall from November to April. The relief is smooth corrugated with 
slope varying from $1 \%$ to $8 \%$. The soil of the experimental area is classified Dystrophic Yellow Latosol (Pragana et al., 2012).

\section{Plant materials}

The cultivar used was the IPRO M8349, which has the following characteristics: maturation group 8.3; determined growth; 111 days average cycle; lodging resistance; recommended population for manufacturer of 280,000 plants/ha. This cultivar was used in the experiment because it is the most planted INTACTA variety in MATOPIBA.

\section{Treatments}

The experiment was completely randomized with four replicates. The main plots consisted of different row spacing $(17.5 \mathrm{~cm}, 25 \mathrm{~cm}, 50 \mathrm{~cm}$, and $76 \mathrm{~cm})$ and subplots with the plant populations recommended for manufacturer for the cultivar $(280,000$ plants/ha), $50 \%$ below recommended (190,000plants/ha), 50\% (420,000 plants/ha) and $100 \%$ higher than recommended (560,000 plants/ha). The subdivided plots had six lines each of five metres in length.

\section{Conduct of study}

The seeds were inoculated with Bradyrhizobiumelkanii and Bradyrhizobiumjaponicum bacteria, and treated with fungicide. Soil correction and fertilization were carried out based on the soil analysis (Table 1), with the application of $100 \mathrm{Kg} \mathrm{ha}^{-1}$ of $\mathrm{KCl}$ and $100 \mathrm{Kg}^{-1}$ of $\mathrm{P}_{2} \mathrm{O}_{5}$ 09-46-00.

During the experiment, climatic data regarding precipitation, relative humidity and air temperature (Fig. 1) were collected, as well as pest and weed control to maximize the culture. The first growth analysis occurred one week after thinning, and data was collected every seven days, with five evaluations. Five plants were randomly scored, the two lateral lines being scanned at $0.5 \mathrm{~m}$ from the ends of each plant line. Sowing was done manually, and thinning was done when the plants reached phenological stage $\mathrm{V} 4$, in order to obtain the desired population for each treatment.

\section{Traits measured}

During the experiment the following growth evaluations were performed: plant height using a ruler and measuring from the stem base to the apical meristem. Stem diameter was expressed in millimetres using digital calipers (Digimess ${ }^{\circledR}$ ), two centimetres from the ground. The number of nodes was determined by counting the number of stem nodes.

After harvesting, the seeds were dried in natural conditions until the water content reached 13\%; afterwards they were taken to the Plant Science Laboratory of Universidade Federal de Piauí, in Bom Jesus, Brazil, where various evaluations of the yield components were performed. The number of grains per pod was determined by the mean number of seeds divided by the average number of pods selected from the plot area (Dalchiavon and Carvalho 2012). The number of grains per plant was counted separately, after the average of the plants was obtained from the plot area (Dalchiavon and Carvalho
2012). The number of pods per plant was obtained by the relation between the number of pods with the plot area and then the average was calculated (Dalchiavon and Carvalho 2012). The weight of one thousand seeds was obtained from eight subsamples of 100 seeds of each treatment. Based on the weight of the subsamples, the mean, variance, standard deviation and coefficient of variation were calculated to obtain the weight of 1000 seeds, with results expressed in grams (BRASIL 2009). The total grain weight in plants was transformed to $\mathrm{kg} / \mathrm{h}$ a and corrected to $13 \%$ of water content in the wet basis (Dalchiavon and Carvalho 2012). Productivity was done by weighing the grains of all the plants in the useful area and transformed to $\mathrm{kg} \mathrm{ha}^{-1}$ (Dalchiavon and Carvalho 2012).

\section{Statistical analysis}

The data were submitted to analysis of variance, and the significance of the mean squares obtained was tested by the response surface test. Plant population data were submitted to calculated regression analysis for linear and quadratic equations and the significant equations up to $5 \%$ of probability were accepted by the $\mathrm{F}$ test, with the highest coefficient of determination (R2). The data referring to the productivity character underwent transformation to $1 / P R O D$, being called PRODt.

\section{Conclusion}

In the local conditions of the experiment (Piauí cerrado savanna), the parameters plant height and number of nodes in the largest spacing $(50 \mathrm{~cm}$ and $76 \mathrm{~cm})$ and in the smallest populations (recommended and $50 \%$ below recommended) present better plant development. Yield components (number of grains per pod, number of grains per plant, number of pods per plant, weight of one thousand seeds and productivity) with better performance are observed in the larger spaces $(50 \mathrm{~cm}$ and $76 \mathrm{~cm}$ ) and in the recommended population for the cultivar.

\section{References}

Basol T, Wright D, Lenssen A (2013) Understanding soybean plant population recommendations for lowa. lowa State University of Science and Technology, $3 \mathrm{p}$.

Brasil. Ministério da Agricultura e Reforma Agrária. Secretaria Nacional de defesa Agropecuária. (2009) Regras para análise de sementes. 395p.

Cruz SCS, Sena-Junior DG, Santos DMA, Lunezzo LO, Machado CG (2016) Cultivo de soja sob diferentes densidades de semeadura e arranjos espaciais. Rev de Agri Neotropical 3(1): p. 1-6.

Dalchiavon FC, Carvalho MP (2012) Correlação linear e espacial dos componentes de produção e produtividade da soja. Ciên Agrárias. 33(2):541-552.

Heiffig LS, Câmara GMS, Marques LA, Pedroso DB, Piedade SMS (2006) Fechamento e índice de área foliar da cultura da soja em diferentes arranjos espaciais. Bragantia. 65(2):285295. 
Lima SF, Alvarez RCF, Theodoro GF, Bavaresco M, Silva KS (2012) Efeito da semeadura em linhas cruzadas sobre a produtividade de grãos e a severidade da ferrugem asiática da soja. Bioscience J. 28(6):954-962.

Ludwig MP, Dutra LMC, Lucca Filho OA, Zabot L, Jauer A, Uhry D (2011) Populações de plantas na cultura da soja em cultivares convencionais e Roundup Ready TM. Revista Ceres. 58(3):305 313.

Ludwig MP, Dutra LMC, Lucca Filho OA, Zabot L, Uhry D, Lisboa $\mathrm{JI}$, Jauer A (2010) Características morfológicas de cultivares de soja convencionais e Roundup ReadyTM em função da época e densidade de semeadura. Ciência Rural. 40(4):759767.

Marchiori LFS, Camara GMS, Peixoto CP, Matins MC (1999) Desempenho vegetativo de cultivares de soja [Glycine max (L.) Merrill] em épocas normal e safrinha. Scien Agrí. 52(2): p.383-390.

Martins MC, Câmara GMS, Peixoto CP, Marchiori LFS, Leonardo V, Mattiazzi P(1999) Épocas de semeadura, densidades de plantas e desempenho vegetativo de cultivares de soja. Scientia Agricola. 56(4):851-858

Mauad M, Silva TLB, Neto AIA, Abreu VG (2010) Influência da densidade de semeadura sobre características agronômicas na cultura da soja. Agrarian. 3(9):175-181.

Modolo AJ, Schidlowski LL, Storck L, Benin G, Vargas TO, Trogello E (2016) Rendimento de soja em função do arranjo de plantas. Rev de Agri. 91(3):216 - 229.

Paiva JB, Teófilo EM, Martins JBP (1992) Densidade de plantio da cultura da soja, Glycine max (L.) Merril, no estado do Ceará. Ciên Agron. 23(1/2):103-107.

Peixoto CP, Câmara GMS, Martins MC, Marchiori LFS, Guerzoni RA, MattiazziP (2000) Épocas de semeadura e densidade de plantas de soja: I. Componentes da produção e rendimento de grãos. Sci Agri. 57(1):89-96.
Petter FA, da Silva JA, Zuffo AM, Andrade FR, Pacheco LP, de Almeida FA (2016) Elevada densidade de semeadura aumenta a produtividade da soja? Respostas da radiação fotossinteticamente ativa. Bragantia. 75(2):173-183.

Pires JLF, Costa JA, Thomas AL, Maehler AR (2000) Efeito de populações e espaçamentos sobre o potencial de rendimento da soja durante a ontogenia. Pesq Agrop Bras. 35(8):1541-1547.

Pragana RB, Ribeiro MR, Nóbrega JCA, Ribeiro Filho MR, Costa JA (2012) Qualidade física de Latossolos Amarelos sob plantio direto na região do cerrado piauiense. Rev Bras de Ciên Solo. 36(5):1591-1600.

Rahman M M, Hossain MM (2011) Plant density effects on growth, yield and yield components of two soybean varieties under equidistant planting arrangement. Asian J Plant Sci. 10(5):278-286.

Rambo L, Costa JA, Pires JLF, Parcianello G, Ferreira FG (2003) Rendimento de grãos da soja em função do arranjo de plantas. Ciê Rural. 33(3):405-411.

Silva LS, Moura M da CCL, Moura R de N, Valadares RG, da Silva AFA (2010) Seleção de variedades de soja em função da densidade de plantio, na microrregião de chapadinha, nordeste maranhense. ACSA. 6:07-14.

Souza R, Teixeira I, Reis E, Silva A (2016) Soybean morphophysiology and yield response to seeding systems and plant populations. Chil J Agric Res. 76(1):3-8.

Torres FE, David GV, Teodoro PE, Ribeiro LP, Correa CG, Luz Júnior RA (2015) Desempenho agronómico e dissimilaridade genética entre genótipos de soja. Rev de Ciê Agrá. 38(1): 111-117.

Tourino MCC, Rezende PM, Salvador N (2002) Espaçamento, densidade e uniformidade de semeadura na produtividade e características agronômicas da soja. Pesq Agrop Bras. 37(8): 1071-1077. 